\title{
INTRODUKSI GEN METALLOTHIONEIN TIPE II KE DALAM RUMPUT LAUT Kappaphycus alvarezii MENGGUNAKAN Agrobacterium tumefaciens
}

\author{
Ulia Fajriah", Emma Suryati ${ }^{* *}$, Andi Parenrengi ${ }^{* *}$, Suharsono ${ }^{* * *}$, dan \\ Utut Widyastuti"i*a) \\ *) Mahasiswa Bioteknologi Program Pascasarjana Institut Pertanian Bogor \\ Jl. Raya Darmaga, Gedung Andi Hakim Nasoetion Kampus IPB Darmaga, Bogor 16680 \\ E-mail: uliafajriah@gmail.com \\ **) Balai Penelitian dan Pengembangan Budidaya Air Payau \\ Jl. Makmur Dg. Sitakka No. 129, Maros 90512, Sulawesi Selatan \\ ***) Pusat Penelitian Sumberdaya Hayati dan Bioteknologi dan \\ Departemen Biologi, FMIPA, Institut Pertanian Bogor \\ Jl. Meranti, Kampus IPB Darmaga, Bogor 16680
}

(Naskah diterima: 2 April 2014; Revisi final: 30 Oktober 2014; Disetujui publikasi: 10 November 2014)

\begin{abstract}
ABSTRAK
Kappaphycus alvarezii adalah jenis alga merah yang memproduksi kappa karagenan yang sangat penting untuk industri makanan, farmasi, dan kosmetik. Untuk meningkatkan produksi, diperlukan ketersediaan bahan baku yang baik. Salah satu yang memengaruhi ketersediaan bahan baku adalah kondisi lingkungan perairan untuk budidaya. Metallothionein (MT) adalah protein yang memiliki kemampuan untuk mengikat ion logam seperti $\mathrm{Cd}, \mathrm{Zn}$, dan $\mathrm{Cu}$. Tujuan penelitian ini adalah untuk mengintroduksi gen Metallothionein Tipe II (MaMt2) ke dalam genom K. alvarezii menggunakan Agrobacterium tumefaciens. Talus rumput laut diinokulasi dengan A. tumefaciens mengandung plasmid pIG6-SMt2 yang membawa gen MaMt2, selanjutnya dilakukan seleksi bertingkat menggunakan higromisin $10 \mathrm{mg} / \mathrm{L}$ dan $20 \mathrm{mg} / \mathrm{L}$. Hasil efisiensi transformasi yang diperoleh adalah $27,4 \%$, efisiensi regenerasi tunas transgenik adalah 27,6\%. Analisis molekuler dengan PCR menunjukkan bahwa 13 tunas transgenik mengandung gen MaMt2. Tunas transgenik putatif ditumbuhkan hingga menjadi talus baru dan dapat dilakukan uji tantang pada penelitian selanjutnya.
\end{abstract}

KATA KUNCl: Kappaphycus alvarezii, MaMt2, transformasi genetik, alga merah

ABSTRACT: Introduction of Metallothionein Type II gene to Kappaphycus alvarezii using Agrobacterium tumefaciens. By: Ulia Fajriah, Emma Suryati, Andi Parenrengi, Suharsono, and Utut Widyastuti

Kappaphycus alvarezii is a type of red algae producing kappa carrageenan that very important for food industry, pharmaceuticals, and cosmetics. To increase the production of raw materials, we need availability of good raw materials. One that affects the availability of raw materials is water environment conditions for cultivation. Metallothionein (MT) is a protein that has the ability to bind metal ions such as Cd, $\mathrm{Zn}$, and $\mathrm{Cu}$. The aims of this study was to introduce Metallothionein Type II genes (MaMt2) into the genome $K$. alvarezii using Agrobacterium tumefaciens. Thallus 
seaweed inoculated with A. tumefaciens containing plasmid pIG6-SMt2 carrying MaMt2 gene, then performed multilevel selection using hygromycin of $10 \mathrm{mg} / \mathrm{L}$ and $20 \mathrm{mg} / \mathrm{L}$. The transformation efficiency in $\mathrm{K}$. alvarezii was $27.4 \%$, the efficiency regeneration of transgenic shoots was $27.6 \%$. Molecular analysis by PCR showed that 13 putative transgenic shoots was contained MaMt2 gene. Putative transgenic shoots were grown up to be a clump of new thallus and challenge test can be done in the future studies.

\section{KEYWORDS: Kappaphycus alvarezii, MaMt2, genetic transformation, red algae}

\section{PENDAHULUAN}

Kappaphychus alvarezii (DOTY) atau Eucheuma cottonii merupakan spesies alga merah (Rhodophyta, Gigartinales, Areschougiaceae) yang mengandung karagenan jenis kappa, jenis fikokoloid yang sangat penting bagi industri makanan, farmasi, dan kosmetik (Bindu \& Levine, 2011; Hayashi et al., 2011). Berdasarkan data yang dirilis oleh Kementerian Kelautan dan Perikanan (KKP) produksi rumput laut tahun 2012 meningkat menjadi 6,2 juta ton dibandingkan dengan produksi tahun 2011 yang mencapai 5,1 juta ton. KKP juga menargetkan bahwa pada tahun 2014 produksi rumput laut bisa mencapai 10 juta ton (Kembaren, 2013). Peningkatan produksi tersebut harus diimbangi dengan ketersediaan bahan baku yang memiliki kualitas tinggi. Ketersediaan bahan baku dipengaruhi oleh musim, salinitas, suhu, intensitas cahaya, dan kondisi lingkungan perairan yang digunakan untuk membudidayakan rumput laut (Yulianto \& Mira, 2009; Mamboya, 2007).

Polusi menjadi masalah yang serius pada lingkungan perairan pantai yang berakibat langsung terhadap pertumbuhan dan sintasan organisme pantai khususnya pada makroalga (Mamboya, 2007). Efek toksisitas logam berat seperti Cu pada alga sama dengan tanaman tingkat tinggi, menyebabkan fotoinhibitor pada fotosistem Il yang berakibat pada Reactive Oxygen Species (ROS) dan disfungsi kloroplas (Owen et al., 2012).

Metallothionein (MT) merupakan protein dengan berat molekul rendah (4-8 kDa), kaya akan sistein dengan kemampuan mengikat atom logam (Moilanen et al., 1999; Mir et al., 2004). Sintesis metallothionein tidak hanya diinduksi oleh beberapa logam berat seperti $\mathrm{Cd}, \mathrm{Zn}$, dan $\mathrm{Cu}$, tetapi juga menjadi mediator pada stres fisiologis, termasuk hormon dan ROS (Shestivska et al., 2011). Anggraito et al. (2012) telah berhasil melakukan transformasi genetik pada tanaman Nicotiana benthamiana dengan menggunakan gen MaMt2 yang berasal dari Melastoma affine (Suharsono et al., 2009), sehingga diperoleh tanaman $N$. benthamiana transgenik.

Teknologi rekayasa genetika pada rumput laut penting untuk peningkatan mutu genetik rumput laut. Peningkatan mutu genetik dapat dilakukan dengan kultur jaringan, fusi protoplas, dan transformasi genetik pada rumput laut Porphyra yezoensis (Cheney, 2000). Metode transformasi genetik menggunakan Agrobacterium tumefaciens umum digunakan pada tanaman tingkat tinggi, fungi, khamir, dan sel manusia (Vieira \& Camilo, 2011).

Untuk meningkatkan toleransi rumput laut K. alvarezii terhadap kondisi lingkungan perairan yang tercemar logam berat, maka dapat dilakukan perbaikan genetik dengan mentransfer gen MaMt2 pada K. alvarezii menggunakan perantara A. tumefaciens. Dengan meningkatkan ekspresi gen MaMt2, diharapkan akan meningkatkan pertahanan rumput laut terhadap kondisi lingkungan yang ekstrim. Penelitian ini bertujuan untuk mengintroduksi gen MaMt2 ke dalam genom rumput laut $K$. alvarezii melalui perantara $A$. tumefaciens.

\section{BAHAN DAN METODE}

\section{Bahan Penelitian}

Bahan percobaan yang digunakan meliputi talus rumput laut $K$. alvarezii yang diperoleh dari Balai Penelitian dan Pengembangan Budidaya Air Payau (BPPBAP) Maros, larutan media pertumbuhan rumput laut Provasoli Enrichment Seawater (PES), kultur Agrobacterium tumefaciens strain LBA4404 mengandung plasmid plG6-SMt2 yang membawa gen MaMt2 (Suharsono et al., 2009) dengan promotor ubiquitin (Anggraito, 2012). Peta plasmid pIG6SMt2 yang membawa gen MaMt2 disajikan pada Gambar 1. Pasangan primer UbiQF (5'- 


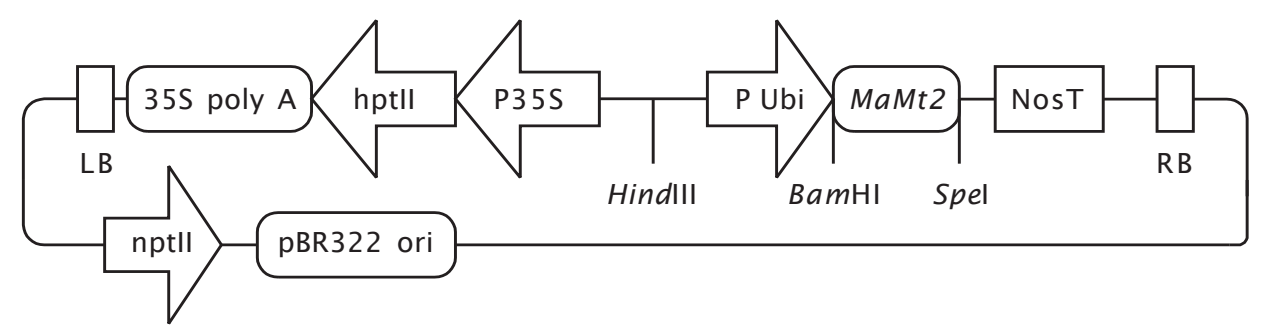

Gambar 1. Peta fisik plasmid plG6-SMt2 (Anggraito, 2012)

Figure 1. Physical map of the plasmid pIG6-SMt2 (Anggraito, 2012)

TGATGGCCCTGCCTTCATACG-3') dan NosTR2 (5'-TGCCGGTCTTGCGATGATTA-3'), SMt2UF (5'-TCATGGATCCATGTCTTGCTGTGGAGG-3') dan NosTR1 (5'-CTCATAAATAACGTCATCCATT ACA-3') yang didesain oleh Anggraito (2012) digunakan untuk mendeteksi keberadaan gen MaMt2 di dalam genom rumput laut transgenik.

\section{Metode Penelitian}

\section{Persiapan rumput laut}

Metode persiapan hingga pemeliharaan bibit rumput laut menggunakan metode yang dilakukan oleh Suryati et al. (2011) yang telah dimodifikasi. Talus rumput laut yang digunakan sebagai eksplan diperoleh dari BPPBAP, Maros. Talus yang sehat dipotong sepanjang $5 \mathrm{~cm}$ dan dibersihkan dari kotoran yang menempel. Sterilisasi dilakukan menggunakan 1\% larutan iodine dan 0,05\% larutan antibiotik. Eksplan yang telah steril ditumbuhkan pada media PES cair, menggunakan shaker kecepatan $100 \mathrm{rpm}$ dengan suhu $23^{\circ} \mathrm{C}$ selama satu minggu. Eksplan yang bertahan hidup selanjutnya dipotong sepanjang $2 \mathrm{~cm}$ dan dikultur selama satu bulan dengan subkultur dilakukan setiap dua minggu sekali. Eksplan siap diinokulasi dengan $A$. tumefaciens.

\section{Kokultivasi}

Metode transformasi genetik pada rumput laut $K$. alvarezii menggunakan metode Cheney (2000) dan Anggraito (2012) yang telah dimodifikasi. Bakteri $A$. tumefaciens strain LBA 4404 yang mengandung plasmid pIG6-SMt2 ditumbuhkan pada $5 \mathrm{~mL}$ media LB yang mengandung antibiotik ( $100 \mathrm{mg} / \mathrm{L}$ streptomisin, $50 \mathrm{mg} / \mathrm{L}$ kanamisin, $50 \mathrm{mg} / \mathrm{L}$ higromisin) pada suhu ruangan, digoyang dengan kecepatan 220 rpm selama dua hari. Suspensi bakteri yang tumbuh selanjutnya disubkultur pada media yang sama selama 18 jam. Bakteri yang tumbuh selanjutnya disentrifugasi dengan kecepatan $5.000 \mathrm{rpm}$ selama lima menit. Pelet bakteri yang diperoleh diresuspensi dengan media PES cair dan penambahan $100 \mu \mathrm{M}$ acetosyringone hingga mencapai $\mathrm{OD}_{600}=0,5-1$.

Eksplan yang siap ditransformasi sebelumnya dilukai dengan menggunakan jarum steril pada permukaan, selanjutnya eksplan dimasukkan ke dalam media infeksi selama 15-60 menit menggunakan shaker dengan kecepatan 100 rpm. Eksplan yang telah diinfeksi dipindahkan pada media kokultivasi berupa media PES cair yang diberi $100 \mu \mathrm{M}$ acetosyringone selama tiga hari pada kondisi gelap.

\section{Seleksi transforman dan identifikasi rumput laut transgenik}

Eksplan yang telah dikokultivasi selanjutnya dibilas dengan air laut steril dan dipindahkan pada media pemulihan (media PES cair dengan penambahan ZPT 0,1 NAA: 0,5 BAP) selama dua minggu. Eksplan yang tumbuh pada media pemulihan dipindahkan pada media seleksi, yaitu media PES cair yang mengandung higromisin $10 \mathrm{mg} / \mathrm{L}$ (seleksi I) dan diinkubasi selama tujuh hari. Eksplan yang hidup pada media seleksi I dipindahkan pada media seleksi II (higromisin $20 \mathrm{mg} / \mathrm{L}$ ) dan diinkubasi selama 14 hari. Eksplan yang tumbuh pada media seleksi selanjutnya dipindahkan pada media regenerasi yang sama dengan media pemulihan hingga tumbuh tunas.

Sebanyak $0,1 \mathrm{~g}$ tunas yang tumbuh pada media regenerasi diisolasi menggunakan metode CTAB oleh Doyle \& Doyle (1990) dengan modifikasi. Modifikasi yang dilakukan adalah penggantian suhu inkubasi $65^{\circ} \mathrm{C}$ dengan suhu $37^{\circ} \mathrm{C}$ selama satu jam. DNA hasil isolasi selanjutnya dianalisis PCR dengan menggunakan pasangan primer UbiQF dan NosTR2, dan pasangan primer Smt2UF dan NosTR1. Campuran reaksi yang digunakan adalah 100 ng DNA 
genom; 0,5 $\mu \mathrm{M}$ masing-masing primer Foward dan Reverse (10 pmol/ $\mu \mathrm{L})$; 1 x buffer PCR; 0,2 mM dNTPmix; 1.25 U Tag DNA Polymerase dan ditambah dengan $\mathrm{ddH}_{2} \mathrm{O}$ hingga volume total reaksi menjadi $20 \mu \mathrm{L}$. Analisis dilakukan dengan kondisi PCR: praPCR $95^{\circ} \mathrm{C}$, lima menit; denaturasi $94^{\circ} \mathrm{C}, 30$ detik; penempelan primer $60^{\circ} \mathrm{C}$, 30 detik; pemanjangan $72^{\circ} \mathrm{C}, 30$ detik dan reaksi dilakukan sebanyak 30 siklus; dan diakhiri dengan pascaPCR $20^{\circ} \mathrm{C}$, sepuluh menit. Hasil PCR dielektroforesis menggunakan $1 \%$ gel agarosa pada 100 volt selama 28 menit. Gel divisualisasi di atas UV transluminator setelah diwarnai dengan $0,5 \mathrm{mg} / \mathrm{L}$ larutan etidium bromida.

\section{HASIL DAN BAHASAN}

\section{Transformasi $K$. alvarezii dengan Gen MaMt2}

Talus yang telah disterilisasi dipotong dengan ukuran $2 \mathrm{~cm}$ (Gambar 2A) dan ditumbuhkan pada media PES cair. Jika pada luka bekas potongan mulai tertutup atau tumbuh bakal tunas baru (Gambar 2B), maka eksplan siap untuk diinokulasi dengan $A$. tumefaciens. Talus yang telah ditumbuhkan pada media kokultivasi (Gambar 2C) terdapat dua jenis, yaitu: 1) Talus yang tidak mengalami perubahan bentuk dan warna, berwarna coklat tua; 2) Talus yang mengalami perubahan warna menjadi coklat muda dan pada bagian ujung terdapat warna kemerahan dan terdapat kerutan pada dinding talus. Eksplan yang mengalami perubahan warna umumnya tidak bertahan lama pada media pemulihan, hal ini ditandai dengan perubahan talus menjadi berwarna putih transparan dan akhirnya mati (Gambar 2D).

Untuk mengetahui eksplan yang terintegrasi dengan gen MaMt2, maka dilakukan seleksi menggunakan agen seleksi yang terdapat pada peta plasmid pIG6-SMt2 yaitu higromisin. Higromisin dan kanamisin adalah agen seleksi yang umum digunakan untuk menentukan keberhasilan dari transformasi
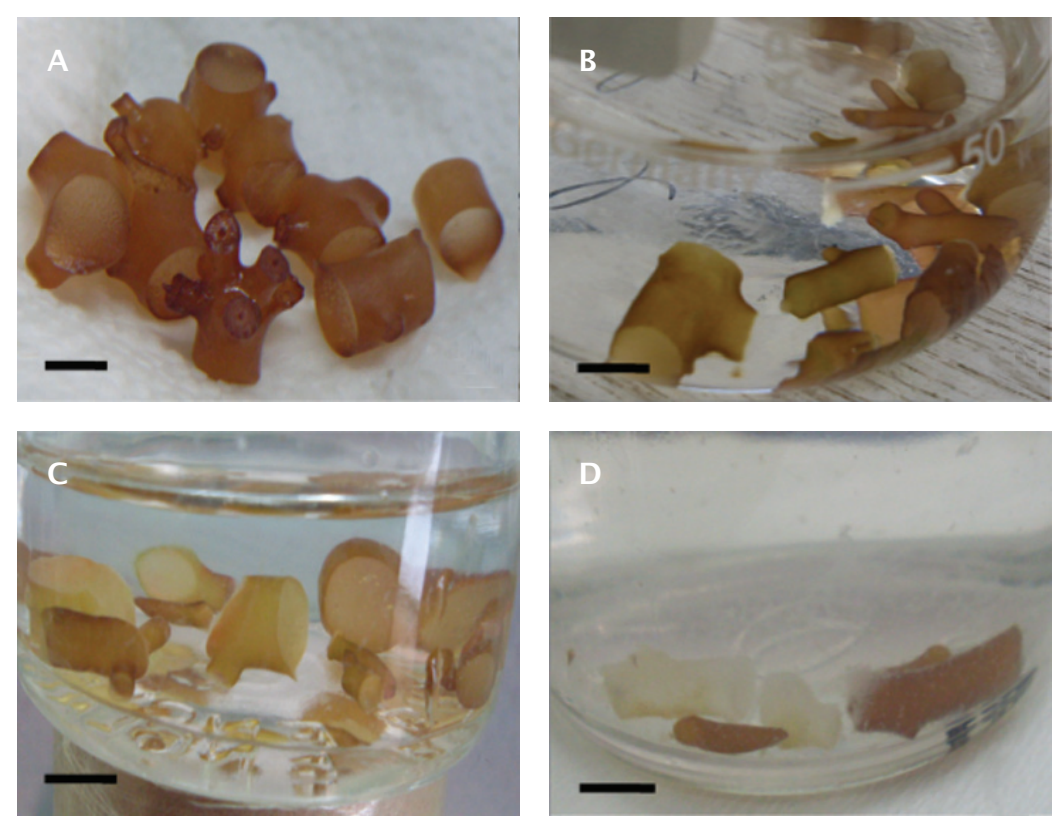

Gambar 2. Tahap inokulasi talus K. alvarezii; eksplan yang telah dipotong dan siap diadaptasikan pada media PES cair (A); eksplan yang siap ditransformasi (B); eksplan pada media kokultivasi (C); eksplan pada media pemulihan (D). Bar $=1 \mathrm{~cm}$

Figure 2. Inoculation stage of $K$. alvarezii thallus; explants were cut and ready to be adapted to PES liquid medium (A); explants were ready to be transformed (B); explants on cocultivation medium (C); explants on recovery medium (D). Bar $=1 \mathrm{~cm}$ 
(Torregrosa et al., 2000). Seleksi higromisin pada penelitian ini dilakukan secara bertingkat, seleksi I dengan konsentrasi higromisin $10 \mathrm{mg} / \mathrm{L}$ selama tujuh hari, dan seleksi II dengan konsentrasi higromisin $20 \mathrm{mg} / \mathrm{L}$ selama 14 hari. Pada penelitian transformasi $K$. alvarezii, Daud (2013) melakukan seleksi menggunakan higromisin dengan konsentrasi 10 $\mathrm{mg} / \mathrm{L}$, dan Handayani (2012) menggunakan higromisin dengan konsentrasi $20 \mathrm{mg} / \mathrm{L}$. Menurut Anggraito (2012), seleksi bertingkat dimaksudkan untuk mendapatkan tanaman transgenik dengan persentase yang lebih tinggi dan mengurangi adanya tanaman transgenik palsu. Tanaman transgenik palsu menurut Torregrosa et al. (2000), adalah tanaman yang mampu bertahan hidup pada media seleksi, tetapi tidak membawa gen ketahanan terhadap agen seleksi tersebut.

Eksplan yang hidup dari media pemulihan ditumbuhkan pada media seleksi I dengan konsentrasi higromisin $10 \mathrm{mg} / \mathrm{L}$ selama tujuh hari. Pada media seleksi I ini hanya 146 eksplan yang bertahan hidup dengan persentase regenerasi sebesar 34,5\% (Tabel 1). Selanjutnya eksplan tersebut ditumbuhkan pada media seleksi Il dengan konsentrasi higromisin yang ditingkatkan menjadi $20 \mathrm{mg} / \mathrm{L}$. Pada media seleksi II hanya 116 eksplan yang dapat bertahan hidup dengan persentase regenerasi sebesar 27,4\% (Tabel 1). Persentase eksplan yang hidup pada media seleksi higromisin ini lebih tinggi dibandingkan dengan persentase hasil seleksi higromisin pada penelitian transformasi $K$. alvarezii yang dilakukan oleh Handayani (2012) sebesar 23,56\% dan penelitian yang dilakukan oleh Daud (2013) sebesar 7,5\%. Faktor yang mempengaruhi keberhasilan tersebut adalah eksplan yang digunakan untuk kokultivasi sudah beradaptasi dengan baik dengan media pertumbuhannya, ditandai dengan bekas luka potongan yang mulai menutup bahkan ada eksplan yang mulai tumbuh bakal tunas. Selain itu, pada penelitian ini menggunakan seleksi bertahap mulai dari dosis higromisin terendah $10 \mathrm{mg} / \mathrm{L}$ kemudian ditingkatkan menjadi $20 \mathrm{mg} / \mathrm{L}$ pada media pertumbuhannya PES cair.

Eksplan yang diperoleh dari hasil seleksi higromisin selanjutnya ditumbuhkan pada media pemulihan. Suryati \& Mulyaningrum (2009) menyatakan bahwa kombinasi ZPT dari golongan auksin dan sitokinin pada media pertumbuhan akan menghasilkan kristal filamen dan embrio rumput laut. Pada penelitian ini diperoleh tunas-tunas baru yang tumbuh pada eksplan yang ditransfomasi (Gambar 3C). Tunas-tunas baru yang tumbuh selanjutnya disebut sebagai tunas transgenik putatif.

Tiga puluh dua eksplan yang tumbuh pada media regenerasi menghasilkan 135 tunas baru $(27,6 \%)$ dan rata-rata pertumbuhan tunas per eksplan sebesar 4,2. Nilai ini lebih rendah dibandingkan dengan persentase tunas dari eksplan yang tidak diinokulasi dengan Agrobacterium yaitu sebesar $70,8 \%$ dengan ratarata pertumbuhan tunas per eksplan sebesar 5,5 . Persentase tunas transgenik putatif ini lebih tinggi dibandingkan dengan persentase tunas transgenik putatif dari Hadayani (2012) yaitu sebesar 11,32\% (kemungkinan dikarenakan penelitian yang dilakukan oleh Handayani memberikan perlakuan antibiotik pada eksplan terlalu lama sehingga banyak menghambat terbentuknya tunas pada eksplan); dan lebih rendah dibandingkan dengan tunas transgenik putatif dari Daud (2013) yaitu sebesar 100\%. Torregrosa et al. (2000) menyatakan bahwa perlakuan antibiotik khususnya higromisin akan menghambat pertumbuhan dan perkembangan tunas pada eksplan. Perkembangan eksplan pada media seleksi disajikan pada Gambar 3.

\section{Analisis Integrasi Gen Mamt2 pada K. alvarezii}

Tunas baru yang tumbuh pada eksplan di media regenerasi selanjutnya diisolasi DNA dan dianalisis PCR. Sebanyak 135 tunas baru yang tumbuh pada eksplan, dianalisis menggunakan pasangan primer dari promotor-terminator dan gen-terminator. Hasil analisis PCR dapat dilihat pada Gambar 4.

Analisis PCR pada tunas transgenik putatif pada kolom 1-4 menggunakan primer Ubi QF-NosTR2, menghasilkan pita berukuran 431 pb. Hasil ini sesuai dengan kontrol positif dari plasmid pIG6-SMt2. Hasil PCR tersebut dikonfirmasi ulang menggunakan primer Smt2FNosTR1 dengan pita berukuran 450 pb. Pita yang dihasilkan sesuai dengan kontrol positif yang menggunakan DNA dari plasmid pIG6SMt2. Pita yang dihasilkan menunjukkan bahwa tunas rumput laut yang dianalisis adalah tanaman transgenik yang mengandung gen MaMt2.

Konfirmasi menggunakan primer yang sama juga dilakukan pada DNA rumput laut nontransgenik (Gambar 4 kolom 2 dan 9). Hasil 


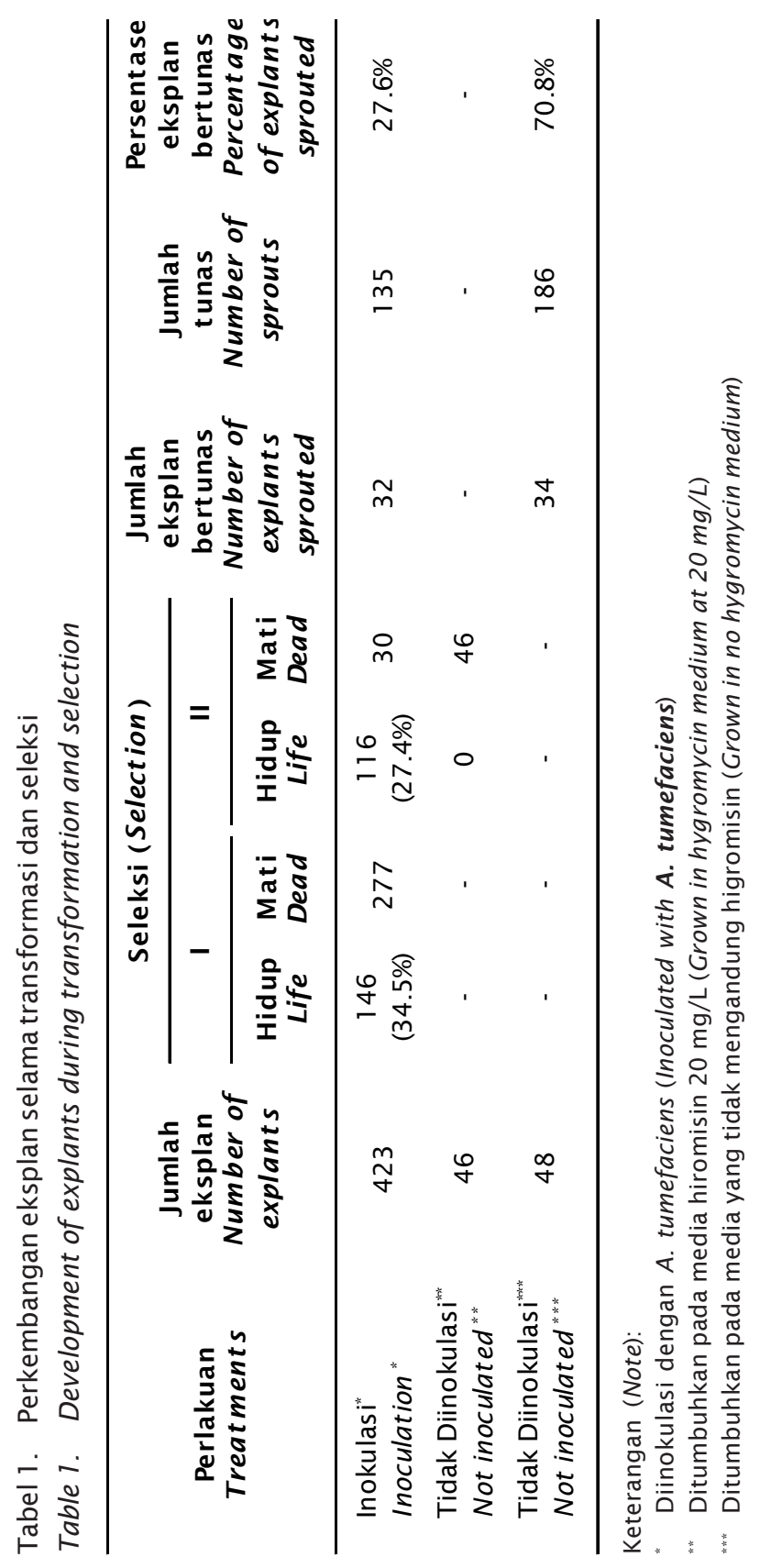



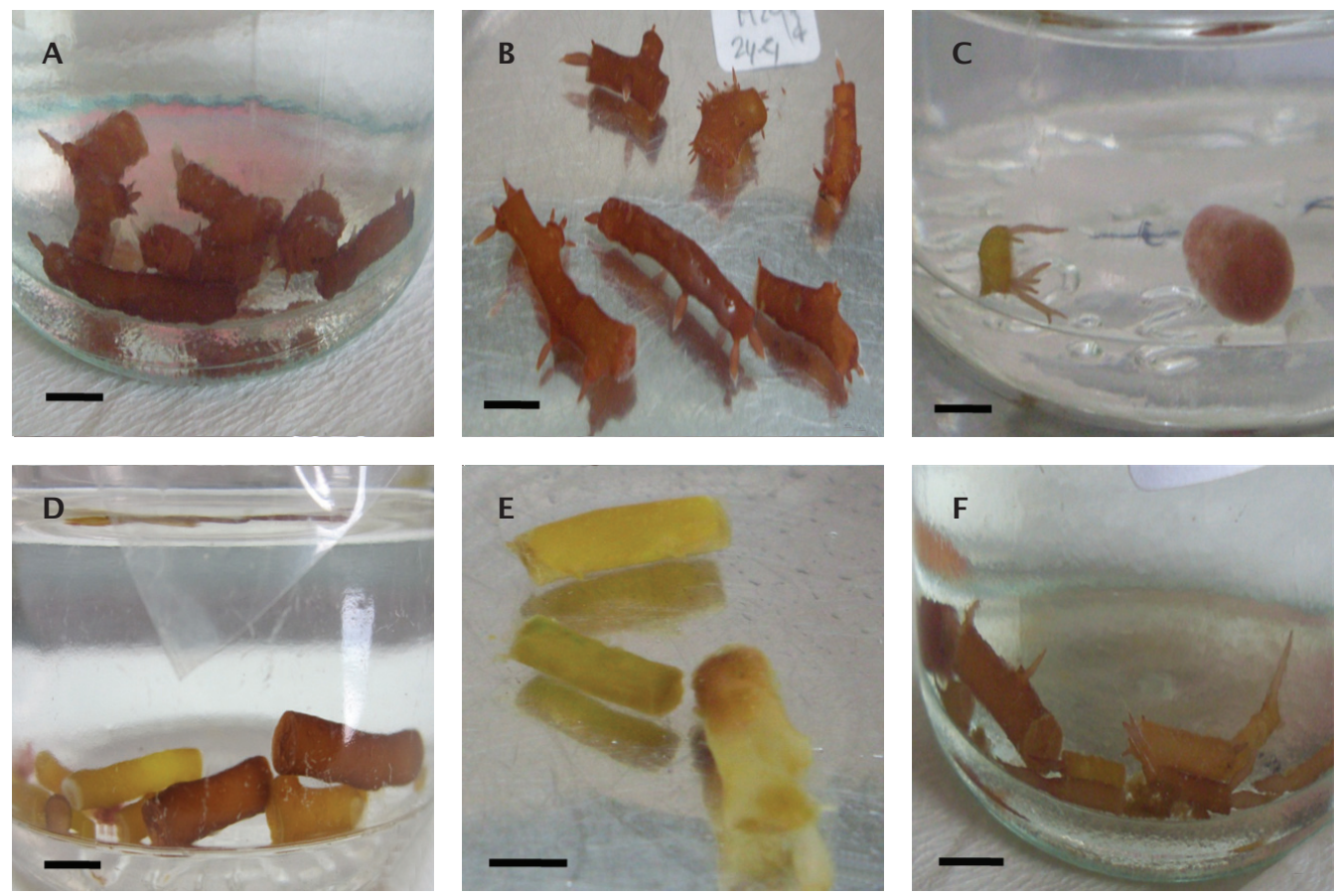

Gambar 3. Perkembangan eksplan pada media seleksi; eksplan transforman di media seleksi I (higromisin $10 \mathrm{mg} / \mathrm{L}$ ) (A); eksplan transforman di media seleksi Il (higromisin $20 \mathrm{mg} / \mathrm{L}$ ) (B); eksplan transforman di media regenerasi (C); eksplan non-transforman di media seleksi I (higromisin 10 mg/L) (D); eksplan non-transforman di media seleksi Il (higromi$\sin 20 \mathrm{mg} / \mathrm{L})(\mathrm{E})$; eksplan non-transforman di media regenerasi $(\mathrm{F})(\mathrm{Bar}=1 \mathrm{~cm})$

Figure 3. The development of explants on selection medium; explants in first selection medium (hygromycin $10 \mathrm{mg} / \mathrm{L}$ ) (A); explants in second selection medium (hygromycin $20 \mathrm{mg} / \mathrm{L}$ ) (B); explants in regeneration medium (C); explants non-transformants in first selection medium (hygromycin $10 \mathrm{mg} / \mathrm{L}$ ) (D); explants non-transformants in second selection medium (hygromycin $20 \mathrm{mg} / \mathrm{L}$ ) (E); explant non-transformants in regeneration medium $(F)(B a r=1 \mathrm{~cm})$

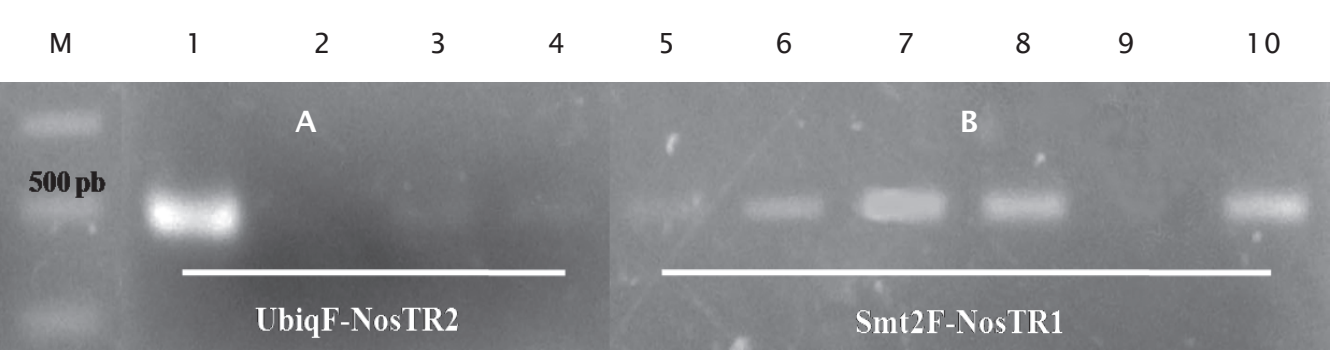

Gambar 4. Hasil analisis PCR; primer UbiqF-NosTR2 (1-4) (A) dan primer Smt2F-NosTR1 (5-10) (B); Kolom $1 \& 10=$ produk PCR dengan cetakan berupa plasmid pIG6-SMt2 sebagai kontrol positif; $2 \& 9=$ rumput laut non-transforman (NT); 3-8 = rumput laut transforman; $M=$ marker $1 \mathrm{~Kb}$

Figure 4. PCR analysis result; UbiqF-NosTR2 primers (1-4) (A) and Smt2F-NosTR1 primers (510) (B); column $1 \& 10=P C R$ product with template plasmid plG6-SMt2 as a positif control; 2 \& 9 = non-transformants seaweed (NT); 3-8 = transformants seaweed; $M=$ marker $1 \mathrm{~Kb}$ 
analisis PCR pada sampel rumput laut nontransgenik tidak menghasilkan pita DNA. Dengan demikian dapat dipastikan bahwa primer yang digunakan spesifik terhadap promotor dan terminator yang terdapat pada plasmid pIG6-SMt2. Dari 135 tunas transgenik putatif yang tumbuh, jumlah tunas yang positif PCR adalah 13 sampel tunas dengan persentase sebesar $9,63 \%$.

\section{Morfologi Rumput Laut Transgenik Putatif}

Eksplan yang mengandung tunas transgenik putatif selanjutnya ditumbuhkan pada media pertumbuhannya (media PES dengan penambahan ZPT 0,5 BAP: 0,1 NAA), namun tunas tersebut mengalami pertumbuhan yang lebih lambat jika dibandingkan dengan tunas non-transgenik pada eksplan yang sama. Tunas transgenik putatif yang berumur tiga bulan memiliki panjang tunas kurang dari $1 \mathrm{~mm}$, sedangkan tunas non-transgenik dengan umur yang sama memiliki panjang tunas $5 \mathrm{~mm}$ (Gambar 5). Pengukuran panjang tunas dilakukan setelah pemotongan ujung tunas untuk isolasi DNA. Perbandingan pertumbuhan tunas rumput laut transgenik putatif dengan tunas nontransgenik dapat dilihat pada Gambar 5.

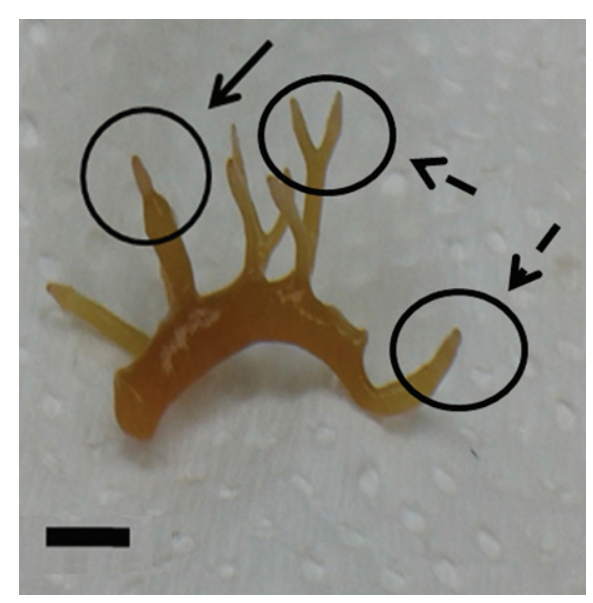

Gambar 5. Pertumbuhan tunas transgenik putatif (tanda panah) dan nontransgenik putatif (tanda panah putus-putus) pada eksplan yang sama $(B a r=1 \mathrm{~mm})$

Figure 5. Growth of transgenic putative shoots (arrow) and non-transgenic putative (dashed arrows) at the same explants (Bar $=1 \mathrm{~mm})$
Tunas transgenik putatif yang diperoleh belum dapat dilakukan uji tantang dengan media yang mengandung logam berat, karena jumlah sampel tunas yang terlalu sedikit. Untuk itu, tunas transgenik putatif selanjutnya ditumbuhkan di dalam tabung erlenmeyer hingga tunas tumbuh menjadi talus baru yang nantinya dapat dipindahkan ke dalam akuarium dan dilakukan pengujian dengan menggunakan air laut yang diberi penambahan logam dengan konsentrasi tertentu.

\section{KESIMPULAN}

Gen MaMt2 pada plasmid pIG6-SMt2 telah berhasil diintroduksikan ke dalam rumput laut K. alvarezii melalui perantara A. tumefaciens. Transformasi genetik diperoleh 13 tunas transgenik putatif dengan dengan persentase pertumbuhan tunas sebesar $27,6 \%$.

\section{UCAPAN TERIMA KASIH}

Ucapan terima kasih diberikan atas riset kerja sama Balai Penelitian dan Pengembangan Budidaya Air Payau (BPPBAP), Maros dengan PPSHB-IPB atas nama Dr. Utut Widyastuti yang telah membiayai penelitian ini.

\section{DAFTAR ACUAN}

Anggraito, Y.U. (2012). Transformasi genetik Nicotiana benthamiana $L$. dan kedelai dengan gen MaMt2 penyandi metallothionein tipe II dari Melastoma malabathricum L. Disertasi. Bogor [ID]: Sekolah Pascasarjana. Institut Pertanian Bogor.

Anggraito, Y.U., Suharsono, Pandal, S.J., \& Sopandie, D. (2012). Konstruksi vektor ekspresi gen MaMt2 penyandi metallothionein tipe II dan introduksinya ke dalam Nicotiana benthamiana. Forum pascasarjana, 35(3), 179-188.

Bindu, M.S. \& Levine, I.A. (2011). The commercial red seaweed Kappaphycus alvarezii an overview on farming and environment. Journal of applied phycolog, 23, 789-796.

Cheney, D.P. (2000). Agrobacterium-mediated genetic transformation of multicellular marine algae, resultant strains and their products. Northeastern University (Huntington Avenue Boston) U.S., 18 pp.

Daud, R.F. (2013). Introduksi gen sitrat sintase ke dalam rumput laut Kappaphycus alvarezii menggunakan Agrobacterium tumefaciens. Tesis. Bogor [ID]: Sekolah Pascasarjana. Institut Pertanian Bogor. Bogor. 
Doyle, J.J. \& Doyle, J.L. (1990). Isolation of plant DNA from fresh tissue. Focus, 12, 13-15.

Handayani, T. (2012). Konstruksi vektor biner dan transformasi gen lisozin pada rumput laut Kappaphycus alvarezii menggunakan Agrobacterium tumefaciens. Tesis. Bogor [ID]: Sekolah Pascasarjana. Institut Pertanian Bogor. Bogor,

Hayashi, L., Faria, G.S.M., Nunes, B.G., Zitta, C.S., Scariot, L.A., Rover, T., Felix, M.R.L., \& Bouzon, Z.L. (2011). Effects of salinity on the growth rate, carrageenan yield, and cellular structure of Kappaphycus alvarezii (rhodophyta, gigartinales) cultured in vitro. Journal of applied phycology, 23, 439-447.

Kembaren, L. (2013). Ekspor rumput 2013, US\$230 Juta. Jurnal Nasional, 10. Retrived from jurnal nasional website: http:// www.jurnas.com/halaman/10/2013-01$17 / 232069$

Mamboya, F.A. (2007). Heavy metal contamination and toxicity: Studies of macroalgae from the tanzania coast. Stockholm University Library. Stockholm. U.S., p. 1-48.

Mir, G., Dome'nech, J., Huguet, G., Guo, W.J., Goldsbrough, P., Atrian, S., \& Molinas, M. (2004). A plant type 2 metallothionein (MT) from cork tissue responds to oxidative stress. Journal of Experimental Botany, 55(408), 2,483-2,493.

Moilanen, Lori, H., Fukushige, T., \& Freedman, J.H. (1999). Identification of upstream regulatory elements and transcription factors responsible for cell-specific expression of the metallothionein genes from Caenorhabditis elegans. Journal of biological chemistry, 274(42), 29,655-29,665.

Owen, J.R., Morris, C.A., Nicolaus, B., Harwood, J.L., \& Kille, P. (2012). Induction of expression of a 14-3-3 gene in response to copper exposure in the marine alga, Fucus vesiculosus. Ecotoxicology, 21, 124-138.

Shestivska, S., Adam, V., Prasek, J., Macek, T., Mackova, M., Havel, L., Diopan, V.,
Zehnalek, J., Hubalek, J., \& Kizek, R. (2011). Investigation of the antioxidant properties of metallothionein in transgenic tobacco plants using voltammetry at a carbon paste electrode. International Journal of electrochemical science, 6, 2,869-2,883.

Suharsono, Trisnaningrum, N., Sulistyaningsih, L.D., \& Widyastuti, U. (2009). Isolation and cloning of cDNA of gene encoding for metallothionein type 2 from Melastoma affine. Biotropia, 16(1), 28-37.

Suryati, E. \& Mulyaningrum, S.R.H. (2009). Regenerasi rumput laut Kappaphycus alvarezii (Doty) melalui induksi kalus dan embrio dengan penambahan hormon perangsang tumbuh secara in vitro. J. Ris. Akuakultur, 4(1), 39-45.

Suryati, E., Fadilah, S., \& Tenriulo, A. (2011). Perkembangan kristal filamen serta pembentukan mikropropagule rumput laut Kappaphycus alvarezii melalui induksi kalus pada media PES 1/20.

Torregrosa, L., Lopez, G., \& Bouquet, A. (2000). Antibiotic sensitivity of grapevine: a comparison between the effect of hygromycin and kanamycin on shoot development of transgenic 110 richter rootstock (Vitis berlandieri $x$ Vitis rupestris). South african journal of enology and viticulture, 21 (1), 3239.

Vieira, A.L.G. \& Camilo, C.M. (2011). Agrobacterium tumefaciens-mediated transformation of the aquatic fungus Blastocladiella emersonii. Fungal Genetics and Biology, 48, 806-811.

Yulianto, K. \& Mira, S. (2009). Budidaya makro alga Kappaphycus alvarezii (Doty) secara vertikal dan gejala penyakit "ice-ice" di perairan Pulau Pari. Dalam Juwana, S. \& Riyatno (Eds.), Oseanologi dan limnologi di Indonesia. Pusat Penelitian Oceanografi dan Penelitian Limnologi. LIPI. Jakarta, 35(3), 325-334. 